http://dx.doi.org/10.12775/szhf.2016.017

\title{
Mariola Wereszka, Psychoterapia to jest moja partia polityczna, Wydawnictwo Różnica, Kraków 2013, ss. 461
}

Psychoterapia, psychologia, psychiatria to częstokroć dla współczesnego człowieka terminy odnoszące się do tego samego predykatu. Gdybyśmy zapytali się kogokolwiek niezwiązanego ze środowiskiem psychologicznym o znaczącą bądź mniej widoczną jakościową różnicę między tymi stanowiskami, to odpowiedziałby pewnie, że są to pokrewne medyczne dziedziny poznania i wiedzy, które ostatecznie mają pomóc jednostkowemu człowiekowi w przezwyciężeniu problemów natury egzystencjalnej i psychicznej. Należy podkreślić, że w latach 60. pojawił się prężnie i dynamicznie działający ruch antypsychiatrii z M. Foucaultem i T. Szaszem na czele. Badacze ci kwestionują psychiatryczną definicję „choroby psychicznej”, stwierdzając, że nie ma ona konotacji ściśle neurologicznych i przyrodniczych, odnosi się zaś do zaburzeń w funkcjonowaniu norm społeczno-kulturowych ${ }^{1}$.

Żyjemy w stechnicyzowanym świecie, dlatego też wiedziemy egzystencję techniczną ${ }^{2}$. Postmodernistyczny świat, w którym nastąpiła relatywizacja norm i wartości szerzy się $\mathrm{w}$ zamęcie odcieleśnionych i odpodmiotowionych form. W XX wieku jedna z najbardziej znanych psychoanalityczek - Karen Horney - zwróciła szczególną uwagę na problematykę coraz częstszego występowania neuroz, czyli neurotycznych zaburzeń. Współcześnie dzierży ster „nałogomania”. Uzależnić możemy się od wszystkiego, jednakże obecnie najbardziej intrygujące i niebezpieczne wydaje się uzależnienie od świata

${ }^{1}$ Zob. A. Kapusta, Szaleństwo i władza: myśl krytyczna Michela Foucaulta. Praca doktorska napisana pod kierunkiem prof. dr hab. Zdzisława Cackowskiego.

${ }^{2}$ M. Bense, Egzystencja techniczna, tłum. I. Sellmer, S. Sellmer, [w:] Kultura techniki. Szkice i studia, Poznań 2001, s. 365. 
wirtualnego. By neutralizować negatywne konsekwencje oddziaływania sieci internetowej na ludzki umysł i stan emocjonalny, należy zwrócić uwagę na to, co podkreślał przede wszystkim twórca dezintegracji pozytywnej Kazimierz Dąbrowski, że jednostki o zbyt niskim potencjale rozwojowym są podatne na uzależnienie, konformizm i streotypizację. By nie doszło do tych destrukcyjnych zjawisk, człowiek winien skupić się na rozwoju autonomicznym, co w ostateczności może doprowadzić do ekskluzji społecznej, czyli wykluczenia. Rozwój psychiczny: ,jest to zdolność do rozwoju w kierunku wszechstronnego rozumienia, przeżywania, odkrywania i tworzenia coraz wyższej hierarchii rzeczywistości i wartości, aż do konkretnego ideału indywidualnego i społecznego"3.

Publikacja zatytułowana Psychoterapia to moja partia polityczna opisuje początki krakowskiego środowiska psychoterapeutycznego, które związane jest z takimi osobistościami, jak: Antoni Kępiński, Maria Orwid, Adam Szymusik, Jerzy Aleksandrowicz, Jacek Bomba, Piotr Drozdowski, Wanda Badura Madej, Bogdan de Barbro i wieloma innymi znakomitymi psychoterapeutami i psychiatrami. Historia tego ruchu zaczęła się w latach 50. XX wieku. Wówczas utożsamiano pojęcie psychiatrii i psychoterapii w Polsce. Od roku 1957 pojawił się termin psychoterapii grupowej, którą prowadził Antoni Kępiński ${ }^{4}$. Dopiero w latach 60. zetknięto się falą egzystencjalizmu w psychiatrii. Było to możliwe dzięki świetnej znajomości języka niemieckiego dr. Aleksandra Teutscha, który tłumaczył i referował Allgemeine Psychopatologie Karla Jaspersa. Powojenna polska psychoterapia była czymś więcej niż wypunktowaniem objawów i „karmieniem” neuroleptykami. Psychoterapia miała charakter wglądu komunikacyjnego i dialogicznego, stąd też możemy odwołać się tutaj do filozofii dialogu. Tischner także był pod ogromnym wpływem filozofii krytycznej Kanta i jego imperatywu traktowania człowieka jako celu oraz odnosił się do idei bezinteresowności dobra. Tischner żył podług maksymy: „Kiedyś filozofia rodziła się z podziwu wobec otaczającego nas świata (Arystoteles). A potem także z wątpienia (Kartezjusz). A teraz, na naszej ziemi, rodzi się ona z bólu. O jakości filozofii decyduje jakość bólu ludzkiego, który chce filozofią wyrażać i któremu chce zaradzaćs".

Natomiast w ten sposób wypowiadał się o fenomenie etyczności:

\footnotetext{
${ }^{3}$ K. Dąbrowski, W poszukiwaniu zdrowia psychicznego, Warszawa 1996, s. 22-23.

${ }^{4}$ M. Wereszka, Psychoterapia to moja partia polityczna, Kraków 2013, s. 41.

${ }^{5}$ J. Tischner, Wobec wartości, Poznań 1982, s. 5.
} 
„Etyka jako specyficzna gałąź filozofii zajmuje się, jak widać, światem dogłębnie ludzkim. Możemy bez przesady rzec, że jest ona teorią doświadczenia drugiego człowieka, a zarazem doświadczenia samego siebie w świetle wynikającym z obecności drugiego ${ }^{6 "}$.

Początkowo ten polski filozof dialogu skupił się na analizie teorii wartości, dopiero w późniejszym czasie zaangażował się w fenomenologiczną analizę i przeżywanie relacji. Psychoterapeuci i psychiatrzy z tzw. „nurtu krakowskiego” starali się patrzeć na „chorego psychicznie” w sposób wielowymiarowy, jak na istotę egzystencjalnie cierpiącą, uwikłaną w nieznajomość swoich procesów psychicznych oraz praw wynikających ze statusu człowieczeństwa. Dlatego też ówczesną psychiatrię krakowską nazywano psychoterapeutyczną. W Warszawie w tamtym okresie działali przede wszystkim wspomniany już przeze mnie Kazimierz Dąbrowski, Stefan Leder (Klinika Nerwic - nurt behawioralno-poznawczy) i Jan Malewski (psychoanaliza). Nurtem psychoanalitycznym zainteresował się również Boguchwał Winid, który wychodził z założenia, że jedynie psychoanaliza reprezentuje prawdziwą wiedzę ${ }^{7}$. Współzałożyciel i były redaktor czasopisma „Psychiatria” - prof. Jerzy Aleksandrowicz - powiedział bardzo przekonująco: „Uważam, że podział psychoterapii na „psychodynamiczne”, „poznawczo-behawioralne”, „systemowe” itp. nie ma większego sensu i nie pomaga $\mathrm{w}$ leczeniu, a poszukiwanie argumentów na ich trafność, „dowodów naukowych” znajdowanych w pomiarach efektywności, tylko wprowadza w błąd"8.

W latach 70. dotarły do Polski idee związane z psychologią humanistyczną (psychologia postaci, analiza transakcyjna czy psychodrama i psychologia self), w związku z czym pojawiły się nowe trendy w psychoterapii kładące nacisk na to, by pozostać $\mathrm{w}$ głębszej relacji z pacjentem/klientem, innymi ludźmi oraz przede wszystkim z samym sobą. W roku 1965 powstała Poradnia Zdrowia Psychicznego dla Studentów, która przyjmowała studentów ze stanami depresyjnymi bądź uzależnieniami. Prof. Jacek Bomba wielokrotnie przywoływał słowa samego Kępińskiego, który głosił, że należy wystrzegać się nihilizmu i pesymizmu terapeutycznego. Oznaczało to, że sam terapeuta nie powinien postrzegać siebie samego jako przepełnionego omnipotencją, a używać takich instrumentów, które pomogą głównie potrzebującemu pacjentowi, nie będą dopasowywać człowieka do terapii, tylko terapię do czło-

\footnotetext{
6 Tamże.

${ }^{7}$ M. Wereszka, Psychoterapia to moja partia polityczna, s. 75.

${ }^{8}$ Tamże, s. 90.
} 
wieka, dlatego też krakowska szkoła cechowała się różnorodnością światopoglądową i poznawczą. Warto wspomnieć o tym, że krakowscy badacze dużą wagę przykładali do myślenia asystemowego oraz z dystansem odnosili się do pojęcia kategoryczności, albowiem człowiek wymyka się ścisłej definicji i należy na niego spoglądać holistycznie. Dla środowiska krakowskiej psychoterapii kluczowa jest osobista historia każdego pacjenta, co można dostrzec, gdy powołują się na pojęcie d zi e jo w ości u Heideggera.

W centrum jego uwagi [Heideggera - przyp. A. K.] były takie terminy, jak „proces”, „możliwości”, „projektowanie”, „otwarcie się,, „stawanie się" (terminy używane nagminnie w psychoterapii!). Eliminował on niejako wartość osoby jako podmiotu, w jego tradycyjnym znaczeniu. Nie miał do zaproponowania niczego, co by wzmacniało nasze poczucie oparcia (agnostycyzm w kwestii wartości) ${ }^{9}$.

Piotr Drozdowski (współzałożyciel Rady Programowej Polskiego Towarzystwa Psychodynamicznego) podkreśla, że celem psychoterapii jest zmiana, poznanie zaś jest skutkiem ubocznym. Wychodzi on z założenia, iż psychoterapia jest jednak częścią procesu naukowego, jeśli weźmiemy pod uwagę chociażby problematykę mechanizmów obronnych, które można poddać weryfikacji czy falsyfikacji. Podobnie jest z pojęciem prawdy, która według przedstawicieli analitycznej psychoterapii wchodzi w zakres r e la t y w i z m u p sychodynamiczneg $\mathrm{o}^{10}$. „Podmiotem poznania w terapii jest pewnego rodzaju kreacja, którą $\mathrm{w}$ dialogu tworzy ta para, pacjent i terapeuta. Ten podmiot terapii nie jest tożsamy z pacjentem, my poznajemy pewien konstrukt, który wytwarza w relacji pacjent"11. Psychoterapeuci dokonują obserwacji analitycznej i dochodzą do wniosku, że we współczesnych ponowoczesnych czasach doszło do absolutyzacji pojęcia radości i szczęścia, a gdy tego stanu szczęśliwości brakuje, następuje spadek samopoczucia i forma patologicznego smutku. Ludzie epoki psychofarmakologicznej zapomnieli o tym, że smutek czy melancholia to naturalne stany emocjonalne, bez których ludzka egzystencja pozbawiona byłaby sensu i celu.

Słabość współczesnej kultury polega na tym, że podważone zostały oferty, w jaki sposób przeżywać szczęście, w jaki nieszczęście, jak pozbawiać się naturalnych rytmów smutku czy lęku. To wszystko jest w tej chwili psychopatologizowane, każdy dyskomfort nadaje się do leczenia. Normą jest perma-

\footnotetext{
9 Tamże, s. 220.

10 Tamże, s. 256.

11 Tamże.
} 
nentny stan komfortu. Stąd psychoterapia jest utożsamiana z przywracaniem szczęścia, zadowolenia, czy sensu. Taki jest rys współczesnej kultury ${ }^{12}$.

Jednym z najbardziej znanych i cenionych psychoterapeutów jest obecnie prof. Bogdan de Barbaro, który w swej pracy terapeutycznej stosuje się do zasady pluralizmu psychologicznego. Można zarzucić de Barbaro zbyt szeroko idące myślenie wielomodelowe, jednakże w tym przypadku postmodernistyczna wielowarstwowość jawi się jako użyteczna dla pacjenta. Jedyne, co przeszkadza, to „anarchia intelektualna albo nihilizm moralny, który jest obecny gdzieś tam w kulturze czy w obyczajowości”"13. W swej psychoterapii rodzinnej wprowadza terminologię oraz założenia filozofii spotkania oraz optuje za wprowadzeniem narracyjności, kategorii przestrzeni komunikacyjnej oraz pojęcia dialogu sformułowanego przez Bachtina ${ }^{14}$.

Aleksandra Kondrat Uniwersytet Mikołaja Kopernika, Toruń, Polska moskwa.ros@gmail.com

\footnotetext{
12 Tamże, s. 265.

13 Tamże, s. 319.

${ }^{14}$ „Dialog jest zawsze procesem otwartym, ponieważ myśl jest zawsze polemicznie zabarwiona, wypełniona opozycyjnymi siłami i otwarta na inspiracje z zewnątrz. Poza tym żadna wypowiedź nie istnieje w izolacji od wiadomości konkretnego, przestrzennie usytuowanego bohatera, a dodatkowo każda - implicite lub explicite, faktycznie lub wyobrażeniowo - jest odpowiedzią na wypowiedź kogoś innego, dlatego jej kontekst jest wysoce spersonalizowany". Zob. M. Puchalska-Wasyl, Nasze wewnętrzne dialogi. O dialogiczności jako sposobie funkcjonowania człowieka, Wrocław 2006, s. 15 [za:] B. Józefik, B. Janusz, B. de Barbaro, Koncepcja dialogowego Ja w psychoterapii - założenia teoretyczne, „Psychiatra Polska”, 2012, t. XLVI, nr 5, s. 859.
} 